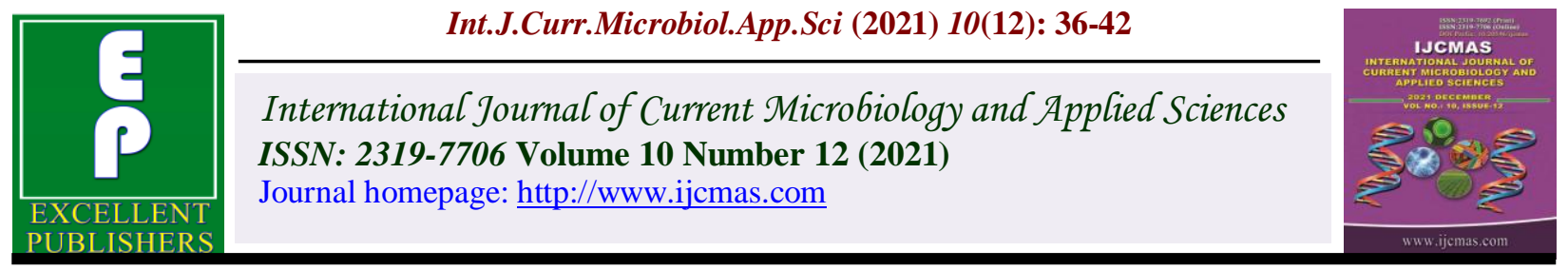

\title{
Performance of Yield and Nutritional Quality of Azolla pinnata Cultivated under Different Water Sources
}

\author{
Sadashiv D. Nimbalkar* and Deepak S. Patil \\ BAIF Development Research Foundation, Central Research Station, Urulikanchan, Ta. \\ Haveli, Dist Pune 412 202, Maharashtra, India \\ *Corresponding author
}

\begin{abstract}
A B S T R A C T
Keywords

Azolla pinnata,

Protein, Yield,

Sources, Water

Article Info

Received:

05 November 2021

Accepted:

30 November 2021

Available Online:

10 December 2021

The performance of yield and nutritional quality of Azolla pinnata cultivated in different water sources like Well water, River water, Bore well, Sewage water and Drainage (water-House) was shows that there is no significant change in yield between the treatments, however, higher yield of $32 \mathrm{~kg}$ fresh Azolla pinnata was observed in river water (T2) and lowest yield of $23.49 \mathrm{~kg}$ in Bore well water $\left(\mathrm{T}_{3}\right)$. Secondly, no significant change in crude protein content between the treatments but highest value of $28.44 \%$ in Sewage water (T4) with an average value of $25.86 \%$ is record. The increased fresh Azolla yield and protein content may be due to lower total dissolved solids, total hardness as $\mathrm{CaCO}_{3}$ and higher in Phosphate availability in the water.
\end{abstract}

\section{Introduction}

Azolla is an aquatic free floating fern belonging to the family Salviniaceae. There are more than seven species grown naturally in various geographical conditions but few species are cultivated considering its nutritional potentiality and adaptability to various climatic conditions. Among these the Azolla pinnata is largely cultivated by the farm due to its high nutritive value, good source of protein with almost all essential amino acid required for animal growth and milk yield. Besides the above, it also contain macronutrients like calcium, magnesium, potassium and vitamins $\mathrm{A}$ and B12 in large quantity. All these facts suggested that Azolla can be used as unconventional feed with protein supplement to livestock including ruminants, poultry and fish (Hossiny et al., 2008) and due to ease of cultivation, high productivity and good nutritive value it is used as a beneficial fodder supplement (Prabina \& Kumar, 2010).

Since, it is floating fern and found in different water sources includes rivers, wells, drainages, lakes and ponds etc. But there is not much 
precision of its quality and quantity of Azolla grown in these water sources. The increased Azolla production is mainly depends on the chemical and biological properties of water and irrespective of water quality the consistent availability of water year around is very much Important to produce required quantity of Azolla for regular use. Therefore, the kitchen waste water is one source which is continuously available and unknowingly wasted in large quantity. In farmers prospective, the use of this water during summer will be the one suitable option to cultivate and produce the Azolla consistently at farmers door step. Similarly, the well and bore well water is also be the alternate options to produce the Azoll on regular bases. Keeping this as an important to farmer's prospective, the trial was conducted to understand the potential yield and nutritional quality of Azolla grown in different water sources.

\section{Materials and Methods}

Considering the benefits and potential of Azolla as a supplementary feed to small and large ruminants, the trial was conducted at BAIF Central Research Station near Pune. The water from different sources were collected like River, Bore well, well, drainage (kitchen waste water). A shade net house was constructed using $90 \%$ shade net in which the 4 x12 ft. size pits were prepared on which silpaulin sheet of 450 GSM was laid on the pits for storing the water.

\section{Steps followed for preparation of Azolla beds are...,}

The $100 \mathrm{~kg}$ clay soil was spread on the silpaulin sheet surface of the bed.

$10 \mathrm{~kg}$ wet cow dung of two days old was made into slurry and sprayed on the soil. Then all the debris were removed to avoid contamination to fresh Azolla and same was continued after every 15 days interval.

The water collected from different sources were poured gently until it reached to 4 inch above the soil surface.

$50 \mathrm{gm}$ of single super phosphate added in all beds and same was continued after every 12 days interval.

$1 \mathrm{~kg}$ of Azolla pinnata culture was spread on each bed (4ft x12ft) and allowed to grow only in one fourth of the surface area for 3-4 days. Once the culture was started to growing, further the same culture was allowed to grow in whole bed.

\section{Treatment details}

$\mathrm{T}_{1}$-Well water, $\mathrm{T}_{2}$-River water, $\mathrm{T}_{3}$-Bore well water, $\mathrm{T}_{4}$-Sewage water and $\mathrm{T}_{5}$-Drainage (Kitchen waste water). The trial was conducted using Randomized Block Design (RBD) with five treatments and replicate each treatments to five times to minimize the error.

After 15 days of inoculation of Azolla culture, the fresh Azolla was harvested from the each of the beds and recorded the weight. The same was continued for every alternate day for 3 months.

\section{Precautionary measures followed during the trial}

The shade net was constructed on top plane surface area to avoid the inflow of water during the rainy season.

If any insect and pest attack observed this may controlled using insecticides and bacterial growth controlled using Bavistin powder.

The care has taken to evade the overflowing of water from the beds during the rainy season. 
After 10 days of Azolla inoculation the bed get cover fully with the fleshy Azolla. During the harvesting care has taken to avoid the disturbance to Azolla. Gently harvested $25 \%$ of Azolla from one corner of the bed.

\section{Results and Discussion}

The fresh Azolla from each treatments were harvested for every alternate day and recorded the weight. The fresh Azolla yield showed higher $32.0 \mathrm{~kg}$ in River water (T-2,) and lowest $23.49 \mathrm{~kg}$ in treatment Bore well water (T-3,) followed by treatment Well water $27.42 \mathrm{~kg}$ (T-1) Sewage water $24.55 \mathrm{~kg}$ (T-4,) and Drainage water -House waste $23.92 \mathrm{~kg}$, (T-5,) (Table 1).

Similarly the highest per day fresh Azolla yield $0.35 \mathrm{~kg}$ was recorded in River water ( $\mathrm{T}$ 2) and lowest $0.261 \mathrm{~kg}$ in Bore well water (T3 ) as shown in the Table 2. The Azolla grown under different water sources is nonsignificant between the treatments. However the per day yield of $350 \mathrm{gm}$ will support as a supplementary nutritive feed requirement to the animals.

Nutritive value of Azolla grown under different water sources (Dry matter basis)

In detail the results of the proximate estimation of sun dried Azolla is shown in the table 3. The average DM content (5.70\%), crude protein $(25.86 \%)$, total ash $(19.37 \%)$, ether extract (4.86\%) ADF (21.51\%), NDF $(45.60 \%)$ Lignin $(11.33 \%$ and Nitrogen. $(4.48 \%)$ were found to be a better use as a supplementary feed to animals. However, within the treatments the highest content of DM recorded was $6.40 \%$ in treatment $\mathrm{T}-4$ (River water), but it is shows lower with compared to $12 \%$ in Azolla pinnata as reported by Akhud et al., (2017).

The study indicates that, no significant change in crude protein content between the treatments but highest value of $28.44 \%$ in Sewage water (T4) (Table 4) with an average value of $25.86 \%$ is recorded and this value is at par with the study conducted by Ahirwar and Leela (2012) and even crude protein value is higher than the values indicated by many researchers i.e. $21.17 \%$ (Sujatha et al., 2013), $21.66 \%$, (Kavya 2014) and $22.5 \%$ (Ashraf and Sharma 2015) the highest

Since the average dry matter value is lower $(5.70 \%)$, the total highest ash recorded is only $21.18 \%$ in T-3 (River water) as compared to the study conducted by Querubin et al., (1986) is $28.70 \%$ and Alalade and Lyayi (2006).

NDF content (percentage of DM) of Azolla pinnata varied from 43.28 to 48.22 with an average value of 45.60 , which is near to the value reported $(39.16,40.36)$ by Alalade and Lyayi, (2006) The ADF content in the study is highest in treatment $\mathrm{T}_{-2}(24.56 \%$, Bore well water), and lowest in treatment $\mathrm{T}_{-5}(18.5 \%$, House waste) and highest ADF value $(24.56 \%)$ is relatively similar with the study conducted by Chatterjee et al., (2013), Kumar et al., (2012), Sharma (2013).

\section{Mineral profiling of Azolla pinnata}

The calcium is one of major mineral required to the growing and milching animals. During milching a large amount of calcium is utilized from the body of the lactating animals. Since the calcium content in Azolla is very high and it will be added advantage to feed the Azolla specially the growing and milching animals. 
Table.1 Fresh Azolla Yield (kg) 3 months period

\begin{tabular}{|c|c|}
\hline Treatment details & Mean $(\mathbf{k g})$ \\
\hline T 1: Well water & 27.42 \\
\hline T 2: River water & 32.00 \\
\hline T 3: Bore well water & 23.49 \\
\hline T 4: Sewage water & 24.55 \\
\hline T 5: Drainage water (House waste) & 23.92 \\
\hline SE(m)+ & 0.979 \\
\hline CD at 5\% & 2.962 \\
\hline CV \% & 8.335 \\
\hline
\end{tabular}

Table.2 Per day average Azolla yield

\begin{tabular}{|c|c|}
\hline Treatments & Mean $(\mathbf{k g})$ \\
\hline T 1: Well water & 0.30 \\
\hline T 2: River water & 0.35 \\
\hline T 3: Bore well water & 0.26 \\
\hline T 4: Sewage water & 0.27 \\
\hline T 5: Drainage water (House waste) & 0.26 \\
\hline
\end{tabular}

Table.3 Nutritive value of Azolla (Dry matter basis) grown in different water sources

\begin{tabular}{|c|c|c|c|c|c|c|}
\hline Nutrients & $\begin{array}{c}\text { T-1 } \\
\text { (Well } \\
\text { water) }\end{array}$ & $\begin{array}{c}\text { T-2 (Bore } \\
\text { well } \\
\text { water) }\end{array}$ & $\begin{array}{c}\text { T-3 (River } \\
\text { water) }\end{array}$ & $\begin{array}{c}\text { T-4 } \\
\text { (Sewage } \\
\text { water) }\end{array}$ & $\begin{array}{c}\text { T-5 } \\
\text { (House } \\
\text { waste) }\end{array}$ & Average \\
\hline $\begin{array}{c}\text { Dry matter (DM } \\
\text { \%) }\end{array}$ & 6.10 & 5.10 & 6.40 & 5.00 & 5.90 & 5.70 \\
\hline Crude Protein (\%) & 25.40 & 27.50 & 25.28 & 28.44 & 22.70 & 25.86 \\
\hline $\begin{array}{c}\text { Total Ash DM } \\
\text { Basis \% }\end{array}$ & 18.25 & 20.33 & 21.18 & 19.12 & 20.47 & 19.87 \\
\hline Ether Extract (\%) & 4.82 & 5.34 & 3.45 & 5.73 & 4.94 & 4.86 \\
\hline $\begin{array}{c}\text { Acid Detergent } \\
\text { Fibre (ADF) }\end{array}$ & 21.32 & 24.56 & 19.45 & 23.71 & 18.5 & 21.51 \\
\hline $\begin{array}{c}\text { Neutral Detergent } \\
\text { Fibre (NDF) }\end{array}$ & 45.32 & 48.22 & 45.2 & 46 & 43.28 & 45.60 \\
\hline Lignin (\%) & 11.58 & 12.50 & 10.50 & 11.21 & 10.85 & 11.33 \\
\hline Nitrogen (\%) & 4.62 & 4.40 & 3.84 & 4.65 & 4.90 & 4.48 \\
\hline
\end{tabular}


Table.4 Mineral profile of Azolla growing in different water sources (Dry matter basis)

\begin{tabular}{|c|c|c|c|c|c|c|}
\hline Minerals & $\begin{array}{c}\text { T-1 (Well } \\
\text { water) }\end{array}$ & $\begin{array}{c}\text { T-2 (Bore } \\
\text { well water) }\end{array}$ & $\begin{array}{c}\text { T-3 (River } \\
\text { water) }\end{array}$ & $\begin{array}{c}\text { T-4 } \\
\text { (Sewage } \\
\text { water) }\end{array}$ & $\begin{array}{c}\text { T-5 } \\
\text { (House } \\
\text { waste) }\end{array}$ & Average \\
\hline Calcium (mg/100g) & 1220 & 1485 & 1120 & 1385 & 850 & 1212 \\
\hline $\begin{array}{c}\text { Phosphorus } \\
\text { (mg/100g) }\end{array}$ & 720 & 856 & 621 & 542 & 780 & 704 \\
\hline $\begin{array}{c}\text { Potassium } \\
\text { (mg/100g) }\end{array}$ & 560 & 678 & 542 & 450 & 582 & 562 \\
\hline
\end{tabular}

Table.5 Analysis of different water sources used for growing of Azolla

\begin{tabular}{|c|c|c|c|c|c|}
\hline Test & $\begin{array}{c}\text { T-1 (Well } \\
\text { water) }\end{array}$ & $\begin{array}{c}\text { T-2 (River } \\
\text { water) }\end{array}$ & $\begin{array}{c}\text { T-3 (Bore } \\
\text { well water) }\end{array}$ & $\begin{array}{c}\text { T-4 } \\
\text { (Sewage } \\
\text { water) }\end{array}$ & $\begin{array}{c}\text { T-5 (House } \\
\text { waste } \\
\text { water) }\end{array}$ \\
\hline pH & 7.4 & 6.94 & 7.02 & 7.19 & 7.3 \\
\hline Total dissolved Solid (mg/l) & 690 & 86 & 478 & 532 & 1142 \\
\hline Total hardness as CaCo $\mathbf{( m g / l )}$ & 285 & 185 & 405 & 250 & 315 \\
\hline Alkalinity as CaCo $\mathbf{( m g / l )}$ & 72 & 81 & 96 & 44 & 58 \\
\hline Chlorides (mg/l) & 258 & 60 & 123 & 113 & 320 \\
\hline Electrical Conductivity (s/cm) & 14 & 48 & 20 & 42 & 61 \\
\hline Turbidity (NTU) & 1.3 & 16.8 & $<1$ & 22.7 & 241.7 \\
\hline Total Suspended Solid (mg/l) & $<5$ & 10 & $<5$ & 10 & 70 \\
\hline Potassium (mg/l) & 0.3 & 6.3 & 0.2 & 6.4 & 14.8 \\
\hline Acidity (mg/l) & Nil & 20.3 & 4.3 & 16.1 & Nil \\
\hline Nitrogen (mg/l) & 5.09 & 1.09 & 6.02 & 0.03 & 5.56 \\
\hline Phosphorus (mg/l) & 0.07 & 2.2 & 0.07 & 0.8 & 0.13 \\
\hline COD (mg/l) & 22 & 27 & 16 & 39 & 46 \\
\hline BOD (mg/l) & 6 & 11 & 8 & 17 & 23 \\
\hline
\end{tabular}

The average value of Mineral profiling of Azolla pinnata shown in the table 4 as Calcium, phosphorus and Potassium are 1212 (mg/100g), $704 \quad(\mathrm{mg} / 100 \mathrm{~g}), \quad$ and 562 (mg/100g) respectively (Table 4$)$. The mineral profiling of Azolla pinnata is relatively similar with the results obtained by Kavya (2014), Anitha (2016).

Analysis of water collected from different sources for growing of Azolla

The growth performance of $A$. pinnata may vary with the types of water used for cultivation. The water of different sources are different chemical and biological properties have impact on growth of the Azolla. The view of the fact, water collected from different sources were tested in laboratory and it was found that the $\mathrm{pH}$ level (6.9 to 7.4) of all the water samples are normal range and hence there is no adverse effect on Azolla growth. The Total Dissolved Solids (TDS) collected ample ranges from 86 to $1142(\mathrm{mg} / \mathrm{l})$ of all the treatments.(Table 5) The TDS of water of Mula mutha River $86 \mathrm{mg} / \mathrm{l}$ is lower than the samples of other water sources used for Azolla cultivation. As per the report, if the tested value of TDS was found above the $2000 \mathrm{mg} / \mathrm{l}$ then it was unsuitable for irrigation purpose or for growth of Azolla. (Ayers R. S. and D. W. Westcot 1994). Hence, the lower TDS in 
treatment T3 (River Water) may be supported high fresh biomass yield (32 kg) as compared to other treatments over the period of three months. Besides, the lower in total hardness $(\mathrm{mg} / \mathrm{l})$, Alkalinity $(\mathrm{mg} / \mathrm{l})$ and Chlorides and higher Phosphorus $(\mathrm{mg} / \mathrm{l})$ in river water may the added advantages for better growth of the Azolla.

The study indicated that, the Azolla pinnata grown in river water is more beneficial as compare to other water sources like Sewage, Well, Bore well and Kitchen waste water. But growing Azolla only in river water may not be suitable to all the farmer who not access to it. Even they can grow the Azolla in other water sources as it was not significant in change in yield. Even the protein rich Azolla can also be produced using sewage water as well and this may also benefit to the farmers rearing the livestock in peri urban area. The fresh or dry Azolla pinnata can used as a supplementary feed to reduce the use of commercial feed and cost in cow, Buffaloes, Goats and poultry rearing farmers.

\section{Acknowledgement}

The authors are thankful to Rajiv Gandhi Science \& Technology Commission (RGSTC), Government of Maharashtra, for financial support to conduct the study and thankful to the scientists at BAIF Central Research Station, Urulikanchan, Ta. Haveli, Dist. Pune 412202 M.S. (India) for cooperation and guidance.

\section{References}

Ahiwar, M. K., and Leela, V. 2012. Nutritive value and In Vitro degradability of Azolla pinnata for ruminants. Indian Veterinary Journal. 89(4): 101-102.

Akhud, H. A., A. M., Ganai, and Beigh, Y. A. 2017. Performance of growing sheep on Azolla based diet. Indian Journal of
Animal Research. 50(5):721-724.

Alalade O A and Lyayi E A. 2006. Chemical composition and the feeding value of Azolla (Azolla pinnata) meal for eggtype chicks. Int. J. Poult. Sci. 5: 137141.

Anitha, K. C, Y. B., Rajeshwari, Prasanna, S. B., and Shilpa S. 2016. Nutritive evaluation of azolla as livestock feed. Journal of Experimental Biology and Agricultural Sciences. 4: 6.

Ashraf, M. A., and Sharma, V. P. 2015. Role of Azolla in controlling mosquito breeding in Ghaziabad District Villages. Indian J. Malarial. 28:51-54.

Ayers, R. S., and Westcot, D. W. 1994.Water quality for agriculture, Soil and Water Specialist (Emeritus) University of California Davis, California, USA

Chatterjee, A, P., Sharma, M. K, Ghosh, M. Mandal, and Roy, P K. 2013. Utilization of Azolla microphylla as feed supplement for crossbred cattle. International Journal of Agriculture and Food Science and Technology. 4(3): 207-214

Hossiny, H, Setoudeh, M., H. Rokni, H. Dehghanzadeh, Cheraghcheshm, M. (2008). Using of silage azollain Guilan male calves nutrition. Proceedings of Third National Congress of Recycling and Reuse of Reneweable Organic Resources in Agriculture Islamic Azad University, Khorasgan branch (Isfshan) Agricultural faculty, waste and water research centre.

Kavya, K., 2014. Nutritional evaluation of Azolla (Azolla pinnata) and its supplementary effect on in vitro digestibility of crop residues and total mixed ration. Ph.D. Thesis submitted to Karnataka Veterinary, Animal and Fisheries Sciences University, Bidar.

Kumar, D S, Prasad, R M. V., Kishor, K. R. and Rao E. R. 2012. Effect of Azolla (Azolla pinnata) based concentrates 
mixture on nutrient utilization in buffalo bulls. Indian J.Anim.Res. 46(3): 268271.

Prabina, B J., and Kumar, K. (2010) Dried Azolla as a nutritionally rich cost effective and immuno-modulatory feed supplement for broilers. The Asian Journal of Animal Science 5: 20-22.

Querubin, L. J., P. F. Alcantara and Princesa, A. O. 1986. Chemical composition of three Azolla species (A. caroliniana, A. microphylla and $A$. pinnata) and feeding value of Azolla meal (A. microphylla) in broiler rations II. Philippine Agriculture. 69:479-490.

Sharma. 2013. Comparative nutritional evaluation \& Effect of supplementation of Azolla microphylla on milk yield and composition in crossbred cattle. MVSc. thesis, NDRI, Kalyani, West Bengal, India.

Sujatha, Kundu, Jeyakumar and Kundu M. 2013. Azolla supplementation: Feed cost benefit in Duck ration in Andaman Islands. Tamil Nadu J. Vet. And Ani Sci. 9 (2): 130-136.

\section{How to cite this article:}

Sadashiv D. Nimbalkar and Deepak S. Patil. 2021. Performance of Yield and Nutritional Quality of Azolla pinnata Cultivated under Different Water Sources. Int.J.Curr.Microbiol.App.Sci. 10(12): 36-42. doi: https://doi.org/10.20546/ijcmas.2021.1012.006 